Kettunen, Lauri 1909: Suhteemme kirjakieleen. - Virittäjä 13 s. 165-168.

— 1910: Väärä suhteemme kirjakieleen. - Virittäjä 14 s. 57-63.

Контамӓкі, Ilmari 1956: Ankara puutarhuri. August Ahlqvist suomen kielen ja kirjallisuuden arvostelijana. Helsinki: Suomalaisen Kirjallisuuden Seura.

Paunonen, Heik i 1976: Kotikielen Seura 1876-1976. - Virittäjä 8o s. 310-432.

— 1993: Suomen mieli - oikea kieli. - Virittäjä 97 s. 81-88.

_ 1994: Kielen normit ja kielen ohjailun normit. - Tiede \& edistys 1/1994 s. 17-28.

— 2006: Vähemmistökielestä varioivaksi valtakieleksi. - Kaisu Juusela \& Katariina Nisula (toim.), Helsinki kieliyhteisönä s. 13-99. Helsinki: Helsingin yliopiston suomen kielen ja kotimaisen kirjallisuuden laitos.
_ 2017: Suomen kieli Helsingissä 1917 ja 2017. Plenaariesitelmä Kielitieteen päivillä 20.5.2017. Jyväskylä.

Peltonen, Vihtori 1906: Mitä suomenkieli suomalaisilta vaatii? - Uusimaa 13.8.1906.

Suometar $1847=$ Suomen kieli kirjallisesti' käytettävänä. - Suometar 11.5.1847.

Talvio, Maila 1909a: Puhe [fennomaanien Nuija-yhdistyksessä]. - Uusi Suometar 18.4.1909.

_ 1909b: Hiukan meistä ja kielestämme. - Uusi Suometar 17.11.1909.

_ 1916: Meidän kielemme. - Suomalainen Suomi 1916 s. 116-125.

Tampereen Sanomat 9.10.1889. Tampere.

TARkiAinen, Viljo 1913: Suomenkielen lausumisesta näyttämöillämme. - Näyttämötaide 1913 n:o 8 s. 153-158.

Uusi Suometar 10.4.1886. Helsinki.

\title{
Kyllä kirjakieltä puhuttu on
}

Jaakko Anhava (2019) kyseenalaistaa tiedon, että Suomen sivistyneistö olisi jossain historian vaiheessa puhunut kirjakieltä. Hän katsoo minun kaiuttavan kirjassani (Lyytikäinen 2016) tätä Heikki Paunosen monissa tutkimuksissaan esiin tuomaa tulosta. Anhavalla on avaintodistajina molemmat isoäitinsä ja isotäti, jotka kaikki ovat työskennelleet opettajina. Käytän samaa metodia ja astun todistajanaitioon.

Olen syntynyt Kymin Karhulassa 1942 ja käynyt siellä kouluni vuosina 1949-1961. Kaikki opettajat - he olivat oppilaitaan sukupolven, pari vanhempia - puhuivat kirjakieltä. Kirjakieli oli minulle aluksi vaikeaa, koska se sisälsi vierasta sanastoa ja morfologiaa, mutta pian siihen tottui.

Kansakoulussa opettajat eivät juuri pyrkineet vaikuttamaan oppilaittensa puheeseen, oppikoulussa sen sijaan pyrkivät, hienovaraisin tai suorin keinoin. Matematiikan opettaja ei sietänyt ilmausta sil- viisii 'sillä tavoin'. Se oli hänen mielestään karkeata murretta. Äidinkielen opettaja neuvoi eksplisiittisesti: "Täällä oppikoulussa ja ainakin äidinkielen tunneilla me puhumme kirjakieltä."

Ehkäpä opettajat suolsivat institutionaalista kieltä, roolipuhetta. En tiedä, miten he ompelu- ja metsästysseuroissaan, kotioloissaan tai ryyppyporukoissa juttelivat, mutta jos ihminen ilmaisee itseään kirjakielellä joka arkipäivä (myös lauantaisin) monta tuntia päivässä, se jättää jälkensä hänen persoonallisuuteensa. Kyllä häntä voi nimittää kirjakielen puhujaksi. Esittelen lisää lapsuuteni kirjakielimaisemaa pian ilmestyvässä teoksessa Sehän on murretta! (Lyytikäinen 2020).

Akateeminen opettajani ja esimieheni, professori, akateemikko Pertti Virtaranta (1918-1997) puhui kirjakieltä. Olen kuvannut hänen kateederikieltään (Lyytikäinen 2018: 125), mutta myös hänen ar- 
kipuheensa oli hyvin kirjakielistä. "Opettajaperheen lapsena hänen varsinainen äidinkielensä oli kirjakieltä lähellä oleva puhuttu yleiskieli, jota oppikoulussa annettu opetus vielä vahvisti", luonnehtii kollega (Hakanen 2018: 18).

Olen kuunnellut kirjailija, akateemikko Mika Waltaria (1908-1979) yli 26 tuntia, kun äänitin kirjallisuudentutkija Ritva Haavikon tekemän haastattelun. Siinä Waltari puhui kirjakieltä, mutta en huomannut hänen haastattelun tauoillakaan muuttuvan puhekielisemmäksi.

Aikanani olen Suomen kielen nauhoitearkiston virkamiehenä kuunnellut paljon Heikki Paunosen tutkimusryhmän 1970-luvun Helsingin puhekielestä tallentamia nauhoitteita. Minun korvissani eräitten vanhojen töölöläisrouvien puhe on hämmästyttävän kirjakielistä. Haastattelupuheen todistusvoima voidaan kyseenalaistaa, mutta oman 40-vuotisen haastattelijankokemukseni perusteella pidän sitä aika luotettavana: harva puhuja jaksaa alkuun päästyään tarkkailla ja säädellä ilmaisuaan.

Mitä "kirjakielen puhuminen" on? Lukupuhunta sikseen, mutta ei kukaan tietysti puhu eikä ole puhunut sataprosenttista kirjakieltä. Se, mistä kaikista piirteistä kirjakielisyyden vaikutelma syn- tyy ja kuinka paljon näitä piirteitä tarvitaan, on vielä pohjia myöten tutkimatta.

ERKKI LYYTIKÄINEN etunimi.sukunimi@elisanet.fi

Kirjoittaja on eläkkeellä Helsingin yliopiston suomen kielen laitoksen amanuenssin toimesta.

\section{Lähteet}

Anhava, JaAkko 2019: Puhuiko Suomen sivistyneistö kirjakieltä? - Virittäjä 123 s. 443-445.

Hakanen, Aimo 2018: Pertti Virtaranta Rautaveden kulttuurimaiseman kasvatteja. - Marja Torikka \& Jaakko Yli-Paavola (toim.), Täyttä työtä. Akateemikko Pertti Virtarannan satavuotismuisto s. 9-27. Helsinki: Karjalan Sivistysseura.

LyYTIKÄINEN, ERKKI 2016: Sanotaan tyyliin näin. Helsinki: Gaudeamus.

2018: Mies ja haave. Suomen kielen nauhoitearkisto. - Marja Torikka \& Jaakko Yli-Paavola (toim.), Täyttä työtä. Akateemikko Pertti Virtarannan satavuotismuisto s. 125-148. Helsinki: Karjalan Sivistysseura.

— 2020 (painossa): Sehän on murretta! Helsinki: Gaudeamus.

\section{Kansainvälinen nimistöntutkijayhteisö koolla Helsingissä}

Elokuussa 2019 Helsinki sai kunnian toimia kansainvälisen nimistöntutkijayhteisön kokoontumispaikkana, sillä Helsingin yliopistossa järjestettiin peräkkäin kaksi merkittävää tieteellistä tapahtumaa: Personal Names and Cultural Reconstructions -konferenssi sekä ICOS Summer School -kesäkoulu. Tässä kirjoituksessa 